\title{
ANAESTHETIC TECHNICIANS IN THE PROVINCE OF QUEBEC
}

\author{
Thomas J. McCaughey"
}

\section{INTRODUCTION}

The first anaesthetic technicians in the Province of Quebec graduated in 1973. These technicians will also be fully trained as "Inhalation Therapists," the Quebec equivalent of the "Respiratory Technologists" of the other Canadian Provinces. The program has been planned and sponsored by the Association of Anesthetists of the Province of Quebec (AAPQ). Like all other paramedical training here, it is given through the CEGEP system (Collège D'Enseignement Général et Professionnel) of the Ministry of Education.

There are bound to be misgivings and frank opposition to this development among some anaesthetists in this Province; they fear a weakening of their traditional role and an attack on their financial security through government policies.

Outside Quebec few anaesthetists know of the recent history behind this development. During the past two years I have had a close-up view of developments as one of four members of the AAPQ which first defined the role of anaesthetic technicians and then planned the program and had it accepted by the AAPQ, the College of Physicians and Surgeons of this Province, now known as the "Professional Corporation of Physicians," and the Ministry of Health.

\section{Inhalation Therapy in the Province of Quebec}

The School of Inhalation Therapy of L'Institut Lavoisier at Hôpital St. Joseph de Rosemont was transferred by order of the Provincial Ministry of Education to Collège de Rosemont on January 31, 1969. This was in line with government policy to raise the academic standards of all paramedical teaching establishments and to control standards of teaching. The Academic Committee of the former school of Lavoisier submitted a lengthy report and recommendations on the new program. The program was extended to three years as it is for other health professionals, such as nurses. In other provinces in Canada the training program for respiratory technologists remains two years in duration.

The Joint Committee on Inhalation Therapy, which combines members from the Canadian Medical Association and the Canadian Anesthetists' Society, heard a full report on this development from its Quebec members at its Annual Meeting in January 1970.

A "Committee on Techniques of Inhalation Therapy" drew up the curriculum for the new CEGEP program. This is a permanent committee, with members from the Ministry of Education, the medical profession and the corporation or organized body of Inhalation Therapy Technicians of Quebec. This committee

\footnotetext{
- Department of Anaesthesia, Montreal Ceneral Hospital, and Department of Anaesthesia, McGill University, Montreal, Quebec.
} 
revises the curriculum and supervises the training in all CEGEPs which have permission to offer this option. The AAPQ accepted official sponsorship of Inhalation Therapy in the Spring of 1970 . It published a brochure defining the structure and status of inhalation therapy in hospitals including a detailed job description. ${ }^{1}$

The AAPQ set up a committee whose terms of reference were to define the role of anaesthetic technicians and to devise a suitable program to train them. Four anaesthetists worked with three delegates from the CEGEP of Rosemont. We clearly understood that the AAPQ had to approve any suggestions we made before they could be proposed for inclusion in CEGEP programs.

In studying the problem, our committee went back to the 1968 Report of the AAPQ on manpower requirements in anaesthesia in Quebec. ${ }^{2}$ The College of Physicians and Surgeons issued a Bulletin on anaesthesia in November 1970, ${ }^{3}$ and we discussed this, particularly since the College emphasized the need for technical assistance to anaesthetists. In defining the possible role of technicians we examined carefully Gravenstein's analysis of tasks performed by anaesthetists. ${ }^{4}$ Our Chairman suggested that we look at some thoughts on this whole subject from the British literature. ${ }^{5}$ After several study sessions the Committee presented a report to the AAPQ.

This report made several important points. It made a distinction between technicians, who should receive special training at the college and aides, who were trained on the job for routine care of equipment. It paid particular attention to the "assistant-médicin en anesthésie." This role has a precise meaning in French and was charged with heavy political overtones for a brief time in 1970. It was an idea largely originating from one French-speaking University, to give university training in health sciences with specialization in anaesthesia. People thus trained would work in collaboration with anaesthetists but could work independently. The explosive possibilities in this proposal attracted much attention from the medical profession. By contrast, the technician in anaesthesia can work only under the complete control of certificated anaesthetists.

The report analyzed all tasks commonly associated with anaesthesia, from the preoperative visit, through the preparation for anaesthesia, the induction and maintenance of anaesthesia and recovery from it; the transport of patients and materials, the servicing, cleaning and sterilizing of equipment. Some of these could be done by aides, some could only be done by physicians and some could be done by a technician either alone or under the supervision of an anaesthetist.

The technician in anaesthesia was seen as having two roles, one technical and one clinical. The technical role is to set up the apparatus used by the anaesthetist. The clinical role includes the monitoring and recording of vital signs and artificial ventilation of patients. This is, of course, the prime role of the inhalation therapist as seen in this Province and is an extension of his activities in Intensive Care Units. $\mathrm{He}$ also measures the adequacy of ventilation but may not insert intraarterial needles or catheters. The anaesthetic technician may not induce anaesthesia or do regional blocks although he may assist in these activities. He may not decide on indications for drugs or on dosages but he may inject them. He may not intubate the trachea except in emergencies. Only the anaesthetist may examine and assess the patient and write orders for medication. The technician may estab- 
lish an intravenous infusion under supervision of the anaesthetist using a needle but not a plastic catheter. Only the anaesthetist decides when extubation may be done though the act itself may be performed by the technician. The technician may take the patient to the recovery room.

The technician may work only under the direct supervision of the anaesthetist who need not, however, be in the room throughout the anaesthetic and may supervise two patients simultaneously.

It seemed to the Committee that there were three possible pathways for the training and education of technicians.

1. They could get their training on the job only. This could lead to unequal standards and abuses.

2. They could be trained by the universities. Here we saw the danger of creating an isolated class of health professional. They would be "almost doctors" and could demand freedom to practice alone. This could threaten anaesthesia as a specialty and would be dangerous for patient care. In addition, the cost of educating these workers would be relatively high.

3. Training through the college system. This seems the best solution and all other health professionals are going through this system also.

The Committce considered both nurses and inhalation therapists as possible technicians in anaesthesia. The curriculum for nurses does not deal in sufficient detail with the physiology of respiration and circulation nor with the mechanics of ventilating equipment. On the other hand, the curriculum for inhalation therapists does. Since all of their three-year program centers on cardiorespiratory care they are the best candidates for assistants in anacsthesia.

This report then indicates the basic thinking of the Committee. It was accepted in this form by the AAPQ in May 1972 together with a suggested curriculum which had been worked out in the closest co-operation with representatives from the CEGEPs. The College of Physicians and Surgeons gave approval. Early in the autumn the Government authorized the setting up of this option through those CEGEPs which were permitted to offer inhalation therapy.

The starting date when announced in November 1972 caught some CEGEPs by surprise. There was to be a modification of those inhalation therapists finishing their training in 1973 to enable them to graduate also as anaesthetic technicians. These students would take extra courses. Students beginning in 1973 would have training as anaesthetic technicians incorporated into their three-year course. This course comprises two years of theory at the CEGEPs and one year of hospital rotation.

\section{The Future: Personal Reflections}

The danger in providing anaesthetic technicians lies in the abuse of their role. The greatest possibility of this is from doctors themselves, and particularly from surgeons.

The creation of technicians could result in the delivery of more and better anaesthetic care to more patients, particularly in rural areas. The trouble is that "more" is not necessarily synonymous with "better". The expansion of surgery is limitless and anaesthetic services have difficulty keeping up with it. Those who would control and monitor anaesthetic practices must in fact regulate the practice 
of surgery. In Quebec the medical profession believes that this is the responsibility of the College of Physicians and Surgeons (Professional Corporation of Physicians). The Professional Corporation, like some other Provincial Colleges in Canada, is surveying patterns of medical practice through the computer facilities of the Health Board. What types and how many operations of a given type are being done are questions which must be answered for each city and district, having in mind the needs of the whole population and the resources available. This sounds political, and, of course, it is. Can the Professional Corporation, always regarded as the doctors' organization, put the needs of the population above traditional liberties of the profession? It will not be easy.

Meantime the Government has mounted "Opération Sciences de la Santé". This is a combined operation of the Ministries of Health and of Education. It is to survey urgent problems in health care and also to make predictions of numbers needed to deliver health care in the five-year period of 1974 to 1979 . Members of the Commission are to make budgetary predictions and also to formulate a preliminary plan for 1979 to 1984. In particular the Commission will forecast the need for and role of existing health professionals and possibly predict the need for new ones. There are eleven subsections, in one of which inhalation therapy is being studied.

The problem for the Government is how it can best use all health professionals to deliver an equal standard of care. It seems to me that it can only control anaesthesia by controlling surgery. Surgical services could flourish like wildflowers everywhere a surgeon (and his family) were willing to live. He could and would take whatever anaesthetic services he could get even if supporting facilities in the hospital (X-ray, laboratory services) were quite poor. Surely Government and the College of Physicians and Surgeons must take decisive action together.

I consider the development of anaesthetic technicians a good thing in its own right. As a specialty, anaesthesia is dying of too much success. As the demand for surgery always exceeds the supply of anaesthetists, we have been forced to compromise, a little at a time. The service load is killing us, we say. Yet our willingness and ability to do more and more risky cases has simply put us on a conveyor belt. The surgeons will not stop and we cannot. We say we want to teach our residents to be better physicians; but our load of work keeps us and them nailed down in the operating room.

The pass rate in our national certifying examination should make us see the red light. We are recruiting second rate residents in many cases in desperation to meet service needs.

We must train better and if necessary fewer physician anaesthetists and teach technicians on the same program. We must teach the Specialist Anaesthetist of the future how to work with technicians. We must teach the technician of the future how to conduct himself in non-teaching as well as in teaching hospitals.

\section{SUMMARY}

I have described the recent history of the development of anaesthetic technicians in the Province of Quebec. Anaesthetic technicians will have the same training program as inhalation therapists. This program is organized through the CEGEP (Collège D'Enseignement Général et Professionnel) system in Quebec. The Asso- 
ciation of Anesthetists of the Province of Quebec (AAPQ) has sponsored inhalation therapy and now sponsors fully the program for training anaesthetic technicians. The Government has approved the program. It is now in operation and the first anaesthetic technicians in Quebec have in fact graduated in 1973.

\section{RÉSUMÉ}

L'auteur rapporte l'histoire récente de la formation de techniciens en anesthésie du Québec. Les techniciens en anesthésie auront la même formation que les techniciens en inhalothérapie. Leur programme d'enseignement est donné dans les CEGEP (Collège d'enseignement général et professionnel).

L'Association des Anesthésistes de la Province de Québec a parrainé l'enseignement des techniciens d'inhalothérapie et elle souscrit maintenant pleinement au programme des techniciens en anesthésie. Le Gouvernement a approuvé le programme d'enseignement qui est opérationnel, les premiers gradués ayant de fait été promus en 1973.

\section{REFERENCES}

1. Inhalothérapie. Structure et descriptions des Taches. 1970. Proposé conjointement par L'Association des Anesthésistes-Réanimateurs de la Province de Québec et par la Corporation des Techniciens Inhalothérapeutes du Québec.

2. Rapport d'un comité spécial de l'AAPQ sur la situation de la main d'œuvre en anesthésieréanimation dans la Province de Québec (1968).

3. Etude sur l'anesthésie-réanimation dans la Province de Québec. Bulletin des Collège des Médecins et Chirurgiens de la Province de Québec, X, 2 (1970).

4. Gravenstein, I.S., Steinhaus, J.E., \& Volpitto, P.P. Analysis of manpower in anesthesiology. Anesthesiology 33: 350 (1970).

5. Tomlin, P.J. The Future, Anaesthesia 22: 354 (1967). 